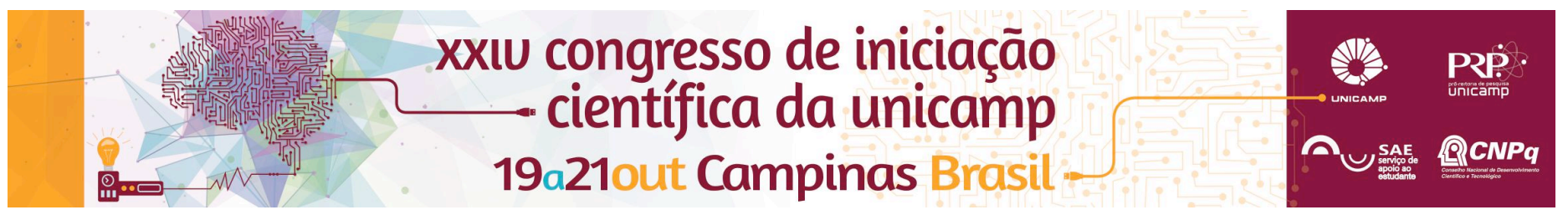

\title{
A teoria do conhecimento no "Teeteto"de Platão
}

\section{Ariane Ribeiro Lindemute de Araújo*}

\section{Resumo}

Este projeto de pesquisa pretende estudar o "Teeteto" de Platão, tendo em vista compreender as dificuldades envolvidas na teoria platônica do conhecimento. O diálogo consiste em uma sucessão de tentativas de definir o que é o conhecimento. $\mathrm{O}$ objetivo do projeto consiste em atingir um mapeamento razoável dos principais argumentos propostos no diálogo, assim como uma compreensão satisfatória das características pelas quais se delimita a crítica platônica às três tentativas de definição.

Palavras-chave

Platão, Teeteto, Teoria do Conhecimento

\section{Introdução}

O "Teeteto" de Platão impõe-se como uma obra fundamental não apenas no âmbito da filosofia do próprio Platão, mas também na filosofia ocidental em seu todo. O diálogo consiste em uma sucessão articulada de tentativas de definir o que é o conhecimento. Nenhuma dessas tentativas apresenta-se como satisfatória aos interlocutores que empreendem a discussão (Sócrates e Teeteto, principalmente, mas também Teodoro), e o diálogo se encerra de modo talvez desapontador, pois não alcança nenhuma definição satisfatória do objeto proposto à investigação. No entanto, apesar do aparente "fracasso" da discussão, o Teeteto configura-se como uma monumental discussão de um dos problemas mais desafiadores da história da filosofia, e, se não alcança nenhum resultado estritamente positivo, com relação à definição de conhecimento, certamente contribui para destruir todas as "falsas pretensões" ao conhecimento. O que resta é um saber negativo, a respeito daquilo que o conhecimento, certamente, não é.

$\mathrm{O}$ objetivo do projeto consiste em atingir um mapeamento minimamente razoável dos principais argumentos propostos no Teeteto, assim como uma compreensão satisfatória das características pelas quais se delimita a crítica platônica às três tentativas de definir o conhecimento (como percepção, como opinião verdadeira, e como opinião verdadeira acompanhada de "logos"). Um dos objetivos principais é discutir o significado de "logos" na parte final do diálogo (declaração, enumeração de elementos, descrição coextensiva).

\section{Resultados e Discussão}

A fonte principal da pesquisa é o diálogo Teeteto de Platão, que será lido em quatro traduções: a tradução para o português de Nunes, para um primeiro contato e para facilitar uma visão sinóptica do diálogo; a tradução inglesa de Levett (com a preciosa introdução de Burnyeat); a tradução comentada de McDowell; a tradução com comentários de F. M. Cornford. Para compor o horizonte conceitual da pesquisa, serão utilizados também outros diálogos de Platão, como o Mênon (por expor situação similar à primeira tentativa de definição, e por expor a tese da reminiscência), o Fédon e a República (por exporem a teoria clássica das Ideias, bem como uma noção de conhecimento como contato direto da alma com os objetivos inteligíveis). O texto grego consultado será sempre o da edição Duke (Oxford Classical Texts).

A bibliografia secundária terá, em primeiro lugar, a introdução de Burnyeat [1990], bem como os comentários de Cornford [1935] e McDowell [1973]. Os livros de Bostock [1988] e Chappell [2004] serão utilizados ocasionalmente. Outros diálogos de Platão serão lidos, preferencialmente, nas traduções de Nunes e nas traduções coligidas em Cooper [1997]. Os demais itens da bibliografia secundária serão lidos de acordo com indicações circunstanciais do orientador.

No momento da presente inscrição (ao XXIV Congresso de Iniciação Científica da Unicamp), o projeto de pesquisa acaba de ser aceito.

\section{Conclusões}

Obviamente, as questões que pretendemos estudar não serão aqui resolvidas de modo definitivo. Mas, se alcançarmos uma formulação clara e satisfatória (com pertinência conceitual e clareza argumentativa) dos problemas interpretativos a serem enfrentados em etapas futuras da pesquisa (inclusive em nível de pós-graduação), cremos que já teremos cumprido os objetivos dessa iniciação científica.

\section{Agradecimentos}

A Lucas Angioni, pela orientação, e aos membros do grupo de pesquisa "Metafísica, Física, Ciência e Dialética em Aristóteles", por ele liderado. Ao SAE e ao CNPq pela bolsa de incentivo à pesquisa do programa PIBIC. 